\title{
Mapping Social Solidarity in Indonesia's Post Conflict Society: A Case Study of Poso
}

\author{
Dwia Aries Tina Pulubuhu ${ }^{1}$, Andi Ahmad Yani², Muhammad Ramli AT ${ }^{3}$, \\ Muhammad Arsyad ${ }^{4}$, Amril Hans ${ }^{5}$, Siti Halwatiah ${ }^{6}$ \\ \{dwiatn@yahoo.com ${ }^{1}$, aayani@unhas.ac.id ${ }^{2}$, mramliat@yahoo.com ${ }^{3}$ \\ arsyad@unhas.ac.id ${ }^{4}$, amrilhans@gmail.com ${ }^{5}$, sitihalwatiah@gmail.com $\left.{ }^{6}\right\}$
}

\begin{abstract}
Department of Sociology, Hasanuddin University, Jl.Perintis Kemerdekaan KM 10, Makassar, Indonesia ${ }^{1,3}$, Department of Administrative Science, Hasanuddin University, Jl.Perintis Kemerdekaan KM 10, Makassar, Indonesia ${ }^{2,5,6}$, Department of Socio-economics of Agriculture, Hasanuddin University Jl.Perintis Kemerdekaan KM 10, Makassar, Indonesia ${ }^{4}$
\end{abstract}

\begin{abstract}
Indonesia experienced communal ethnoreligious conflicts during the political transition from authoritarian era toward a democratic period in 1999-2005. After a decade of violent conflict, the Indonesian government has conducted peacebuilding programs in post-conflict societies in order to redevelop social trust and social solidarity among members of societies that contribute to the peace building process. This study attempts to identify post-conflict societies' quality of social solidarity based on Fessler' study. The study was conducted in Poso Regency, which is a post-religious conflict area. The study employs survey method and has interviewed 373 respondents. The data is analyzed by a descriptive statistic. The results show that Poso people have experienced the collapse of social solidarity due to violent religious conflicts. The majority of respondents feel as part of the community and are always open to open relationships with anyone regardless of ethnic or religious background. Poso young people have positive interpersonal relationships although they have experienced violent conflict, indicating that the Poso community has strong social solidarity.
\end{abstract}

Keywords: social solidarity, post-conflict, society, peacebuilding, conflict resolution

\section{Introduction}

Indonesia after the fall of the Soeharto's military government was marked by increasing ethnic and religious conflicts and communal violence in several areas, such as Ambon, Poso, Sampit, North Luwu, and Mamasa. Likewise, with some conflict-prone areas because of rebels, such as Aceh and Irian Jaya (Papua), which also experienced a high escalation in 1998. This communal conflict resulted in 10,000 deaths from 1997 to 2001[1] and around 1, 3 million people have to flee to avoid becoming victims of those bloody conflicts [2].

The intensity of this communal conflict gradually declined after the government succeeded in breaking down the conflict since 2002 through enhancing public security and insisting conflict groups to halted the conflict with peace talks. For example, peaceful meetings of Malino for terminating ethnoreligious conflicts in Maluku and Poso. Moreover, the Helsinki MoU to end the three-decade of conflict with the Free Aceh movement in 2004. In addition, beside peace 
meeting, the government also applied decentralization policy to enhance the quality of public services and capacity of local government that contribute to violent conflict mitigation [3][4].

Although this conflict has subsided, it does not rule out the possibility of reappearing in a different form. This is supported by study of the World Bank [5], which indicates that there was a transformation of the type of violence after communal violence in the previous decade. According to World Bank's [5] data that communal violence transforms from massive violence to routine violence which can be categorized into five types of violence as following.

First, violence relates to the decentralization of democracy in terms of the implementation of elections or political succession at the local level (province and district levels). Moreover, the split of regions (province or district) tended to involve feuds between ethnic or religious groups. The second type of violence is related to control of resources issues. Violence in this category can be in the form of 3 types of conflicts, namely: conflicts between farmer groups, conflicts between farmers and companies or industries, and conflicts between farmers and the government involving security forces. The third conflict category refers to violence that occurs as a result of weak law enforcement. This type of violence refers to vigilante actions for criminal acts. Moreover, the last type of violence is related to identity, which is a type of violent conflict prevalent in the past decade [5].

The four types of violence are vulnerable to occur in post-conflict communities. The vulnerability of the post-conflict community over the recurrence of conflict is partly due to a lack of social trust and social solidarity[6]. Concept of social solidarity was firstly proposed by Durkheim [7] and argued that social solidarity is an essential element of society [8]. Durkheim identified two types of social solidarity, first is mechanical, which refers to a society governed by collective consciousness and solidarity is built upon likeness and uniform, such as religious groups. The second is organic solidarity that occurs in an organization which characterized with specialization and interdependence. This type of solidarity is developed based on sharing collective understanding and social exchange [9].

This study aims to examine degree of social solidarity of post-conflict society, particularly in Poso Regency. The authors chose Poso as the area study based on two main reasons. First, Poso was one of the areas of religious conflict that involved two conflicting groups between Christians and Moslem with the highest number of fatalities. The study of the Word Bank[10] reported that there were around 600 people who died due to conflict, and around 1000 people were displaced. Thus, post-conflict Poso communities need time to restore social trust and social solidarity. This study is expected to identify progress of peacebuilding development in the postconflict decade by examining Poso society's degree of social solidarity. The second reason is that the conflict in Poso occurred in a relatively long period, which was around four years. The bloody conflict began in late 1998 and gradually declined in mid-2002[11][12][13]. The length of the conflict period has an impact on the level of vulnerability of the post-conflict trauma community to rebuild their social solidarity. Hence, this study proposes a research question as how is Poso society's social solidarity as a post-conflict society?

\section{Method}

This study was conducted in Poso Regency, Central Sulawesi Province because it is a postconflict area and is prone to have re-emergence of conflict. Poso Regency consists of 18 subdistricts with an area of $8,712.25 \mathrm{~km}^{2}$ and has a population of 225,379 inhabitants [14]. The research was conducted in August 2017. 
This study employed a quantitative method by distributing questionnaires in four subdistricts in Poso randomly. There were 450 questionnaires distributed to senior high schools in those areas, and 373 questionnaires or 83 percent were returned. The results of the questionnaire data were analyzed by descriptive statistical method to analyze trend of respondents' tendency to their degree of social solidarity.

This study employs Fessler's [15] measuring method of community solidarity to examine social solidarity in Poso post-conflict society. Fessler[15] identified eight variables of community behavior that reflect solidarity, namely (1) community spirit; (2) interpersonal relation; (3) family responsibility toward community; (4) schools; (5) churches; (6) economic behavior; (7) local government; and (8) tension areas. The study of Fessler was conducted in survey method and distributed a questionnaire to students of senior and junior high schools in eight rural community in Iowa.

Although this study follows the classic study of Fessler [15], however, the study only focuses on five variables namely: 1) community spirit; (2) interpersonal relation; (3) family responsibility toward community; (4) schools; and (5) religious institutions. This study argues that the five variables have presented personal experiences of post-conflict communities and match to socio-cultural context of Indonesian society. The target respondents were asked to identify their perception regarding community behavior. Every variable has five questions with four range answers: "definitely untrue"; "untrue"; "true" and:" very true".

\section{Result and Discussion}

\subsection{Demographic background}

This subsection describes demographic background of respondents. In gender perspective, respondents of the study consist of 221 persons or 59 percent female and 152 persons or 41 percent male. The distribution of gender respondent shows that the study addresses important contribution of women in post-conflict society in which role of women commonly lack of representative in societal issues.

In terms of the religion of the respondents, this study succeeded in interviewing 213 people or 57 percent who are Muslims, 149 people or 40 percent who are Christians and 11 people or 3 percent of respondents who are Hindus. The distribution of respondents who are predominantly Muslim represents the study areas which are areas of conflict in areas that are predominantly Muslim. Some Christians still have not returned yet to their area of origin before the conflict.

This study also identifies ethnicity of respondent, which affect their social relationship among Poso society. As commonly known that Indonesia is a diverse country which has around 1000 ethnic groups and 800 local languages. The Poso community itself consists of five major ethnic groups, namely Pamona, Lore, Tojo, Bungku, and Mori. Composition of ethnicities is critical issue in Poso post conflict society since several studies suggested that prior religious tension, ethnic issue was firstly erupted due to inequality issue between native and migrant groups[16][11]. This study identified thirteen ethnic backgrounds of the respondents, namely: Pamona, Lore, Mori, Bugis, Minahasa, Toraja, Jawa, Maluku, Tionghoa, Bali, Lombok, Kaili, and Mandar. There are 172 persons, or 46 percent are native people, and 201 respondents or 54 percent are migrants. The diverse ethnic background of respondents suggests that this study addresses equal representations of all Poso society's ethnicities. 


\subsection{Dynamic of Poso Society's Social solidarity}

Community spirit. The first variable of social solidarity refers to the intention of all citizens or group of citizens to be involved for the benefit of community. This study examines the spirit of community based on five questions and presented in Table 1 . At the first statement, it appears that the majority of respondents stated that it was not true if the Poso community did not want to work together to solve community problems. This indicates that the majority of respondents felt confident of the community's joint commitment to reduce the emergence of conflict again. At the second statement, the majority of respondents stated themselves as part of the community. This data indicates that 97.4 percent of respondent feel a strong attachment to their community even though they experienced violent communal conflicts a decade ago. Furthermore, the third and fourth statements indicate that most respondents think that Poso residents are not always selfish but rather try to maintain collaboration among community members. This argument is supported by the last statements, which presented that 90 percent (include "true" and "very true") of respondent strongly agreed on the statement which addresses open collaboration among Poso people regardless religious and ethnic background.

Table 1. Statements of spirit of community (in percentage)

\begin{tabular}{lcccc}
\hline \multicolumn{1}{c}{ Statements } & $\begin{array}{c}\text { Definitely } \\
\text { untrue }\end{array}$ & Untrue & True & $\begin{array}{c}\text { Very } \\
\text { True }\end{array}$ \\
\hline $\begin{array}{l}\text { People won't work together to } \\
\text { get things done for the }\end{array}$ & 29.6 & 57 & 10.7 & 2.7 \\
$\begin{array}{l}\text { community } \\
\text { I feel very much that I am part } \\
\text { of the community }\end{array}$ & 1.2 & 1.4 & 42.2 & 55.2 \\
$\begin{array}{l}\text { The people as a whole mind } \\
\text { their own business }\end{array}$ & 16.4 & 48.0 & 27.3 & 6.8 \\
$\begin{array}{l}\text { No one seems to care much } \\
\text { how the community looks }\end{array}$ & 14.0 & 56.0 & 27.1 & 2.9 \\
$\begin{array}{l}\text { Everyone is welcome to } \\
\text { collaborate with anyone } \\
\text { regardless of their religious or } \\
\text { ethnic background }\end{array}$ & 2.4 & 8.0 & 46.4 & 43.2 \\
\hline
\end{tabular}

Interpersonal relation. The second variable of social solidarity is the expression of community members in establishing interpersonal relationships with fellow citizens. The first statement on this second variable indicates that the majority of respondents have no difficulty building friend relationships. This shows that Poso young people are able to establish good friendships despite having experienced a period of conflict. Even so, Table 2 presents there was still 26 percent (include "true" and "very true") of respondents who found it difficult to make friends. The second and third statements indicate the respondent's perception of the attitude of community members to him in their daily activities. This study indicates that there are not too large differences between groups of respondents who have experienced positive and negative experiences. Even so, the number of respondents who experienced positive experiences is slightly higher.

However, the fourth statement gives a stronger indication of the differences between the two groups. This study shows that the majority of respondents feel that other people's 
relationships with themselves are done sincerely and without any intention to take advantage. Even the last statement strengthens the indication that the majority of respondents experienced positive experiences in their interpersonal relationships. Table 2 shows that 89.6 respondents (include "true" and "very true") stated that they always showed good judgment. In short, this data indicates that youth Poso generally have positive interpersonal relationships and have no problems to build personal relationships with their friends or other members of the community.

Table 2. Statements of interpersonal relation (in percentage)

\begin{tabular}{l|c|c|c|c}
\hline \multicolumn{1}{c|}{ Statements } & $\begin{array}{c}\text { Definitely } \\
\text { untrue }\end{array}$ & Untrue & True & $\begin{array}{c}\text { Very } \\
\text { True }\end{array}$ \\
\hline $\begin{array}{l}\text { Real friends are hard to find in } \\
\text { this community }\end{array}$ & 24.9 & 49.1 & 19 & 7 \\
\hline $\begin{array}{l}\text { A lot of people here think that } \\
\text { they are too nice for you }\end{array}$ & 4.8 & 40.8 & 48.8 & 5.1 \\
\hline $\begin{array}{l}\text { Almost everyone is polite and } \\
\text { courteous to you }\end{array}$ & 4.8 & 37.6 & 49.9 & 7.8 \\
\hline $\begin{array}{l}\text { Everyone here tries to take } \\
\text { advantage of you }\end{array}$ & 14.5 & 59.5 & 20.9 & 5.6 \\
\hline $\begin{array}{l}\text { People around here show good } \\
\text { judgment }\end{array}$ & 2.4 & 8.0 & 46.4 & 43.2 \\
\hline
\end{tabular}

Family responsibility. This third variable refers to the roles and responsibilities of the family as a fundamental entity in society by playing a role in building social values to their children based on community norms. The first statement addresses the role of the family in forming family members - their children - to follow social norms. Table 3 shows that the majority of respondents (69 percent include "true" and "very true") support the role of the family as a basic social institution in educating their children. The second statement also confirms the function of the family in carrying out the function of applying norms. The results of the study showed that 96 respondents (include "true" and "very true") confirmed that the Poso community placed the family as a norm training institution, especially in respect of people's right. Then in the third statement, respondents were asked to assess how big the role of the family in their children outside the home. This study indicates that 63.6 respondents (include "definitely untrue" and "untrue") stated that the Poso family who ignored the family were incorrect. This data shows that families try to ensure that their children follow social norms.

Table 3. Statements of family responsibility (in percentage)

\begin{tabular}{lcccc}
\hline \hline \multicolumn{1}{c}{ Statements } & $\begin{array}{c}\text { Definitely } \\
\text { untrue }\end{array}$ & Untrue & True & $\begin{array}{l}\text { Very } \\
\text { True }\end{array}$ \\
\hline $\begin{array}{l}\text { Families in this community keep } \\
\text { their children under control }\end{array}$ & 5.6 & 25.2 & 46.6 & 22.6 \\
$\begin{array}{l}\text { Parents teach their children to } \\
\text { respect others people's right }\end{array}$ & 2.7 & 0.8 & 23.1 & 73.5 \\
$\begin{array}{l}\text { Families are unconcerned about } \\
\text { what their kids do as long as they } \\
\text { keep out of the trouble }\end{array}$ & 19.6 & 44.0 & 30.3 & 6.2 \\
\hline \hline $\begin{array}{l}\text { If their children keep out of the } \\
\text { way, parents are satisfied to let } \\
\text { them do whatever they want to do }\end{array}$ & 45.3 & 42.9 & 7.5 & 4.3 \\
\hline
\end{tabular}




\begin{tabular}{l}
$\begin{array}{l}\text { The community tries as much as } \\
\text { possible to help the younger } \\
\text { generation do good things }\end{array}$ \\
\hline \hline
\end{tabular}

The active role and attention of the family is actively addressed by the fourth statement where the majority of respondents (89 percent include "definitely untrue" and "untrue")) stated that families in the Poso community never allow their children to do anything they want because it is likely to have a negative impact on society. Furthermore, in the final statement, the Table 3 shows that the Poso community was also involved in helping the family's role to ensure their young people did things right and positively contribute to the community. This study shows community behavior of Poso society regarding important role of families and communities in ensuring their children follow social norms. This behavior may relate to the trauma of the Poso society over the four years of violent communal conflict in the past decade triggered by youth fights[17].

Schools. This institution is one of the social institutions that has long played a major role in educating and shaping social norms in the younger generation. School institutions are also expected to contribute to strengthening social solidarity. Table 4 shows respondents' assessments of the social role of school institutions in post-conflict societies. In the first statement, the majority of respondents admitted that schools had done their basic role in literacy education well. At the second statement, this study attempts to see experience of respondents in terms of community acceptance of differences. The data in Table 4 shows that the 54.5 percent (include "true" and "very true" statements) of respondents felt uncomfortable due to differences is slightly higher than another group. This data indicates that some members of post-conflict communities are still reluctant with differences.

Table 4. Statements of school (in percentage)

\begin{tabular}{lcccc}
\hline \multicolumn{1}{c}{ Statements } & $\begin{array}{c}\text { Definitely } \\
\text { untrue }\end{array}$ & Untrue & True & $\begin{array}{l}\text { Very } \\
\text { True }\end{array}$ \\
\hline $\begin{array}{l}\text { Most of students here learn to } \\
\text { read and write well }\end{array}$ & 2.7 & 4 & 55 & 38.3 \\
$\begin{array}{l}\text { People give you a bad time if you } \\
\text { are being different }\end{array}$ & 5.1 & 40.5 & 42.4 & 12.1 \\
$\begin{array}{l}\text { Our schools do a good job of } \\
\text { preparing students for college }\end{array}$ & 2.7 & 10.5 & 52.5 & 34.3 \\
$\begin{array}{l}\text { Our schools do poor job in } \\
\text { preparing young people for live }\end{array}$ & 32.7 & 52 & 14.5 & 0.8 \\
$\begin{array}{l}\text { Many young people in the } \\
\text { community do not finish high } \\
\text { school }\end{array}$ & 3.8 & 17.4 & 53.6 & 25.2 \\
\hline \hline
\end{tabular}

Furthermore, the third and fourth statements show that the majority of respondents acknowledge the success of school institutions in helping young people to be able to continue school to college and prepare young people for life. This data indicates that post-conflict young people have positive expectations for school institutions. However, the latest statement shows that the majority of respondents stated that most Poso young people could not continue their education to a high school level. The results of this study are consistent with data from the Central Poso Statistics Agency[14], which reports that school participation rates at the age of 
high school are lowest when compared to school participation rates at the junior and elementary levels. Poso Statistics shows that of the 100-high school-age population, there are 36 children who do not go to school. Compared with seven children who did not continue school in 100 elementary school-age population and 23 children who did not continue school in 100 middle school age population.

Religious institutions. The last variable of social solidarity which plays critical role in building and maintaining social norms based on spiritual values. As a post-religious conflict society, this variable is very important in seeing the degree of social solidarity after a decade after the conflict. The first statement examines the degree of community obedience to the religion they believe in. Table 5 shows that 84.3 percent (include "true" and "very true") of respondents stated that Poso people were religious even though there were 15 percent who stated otherwise. This data shows the strength of religion as part of the identity of the majority of Poso people, including young people.

Table 5. Statements of religious institutions (in percentage)

\begin{tabular}{lcccc}
\hline \multicolumn{1}{c}{ Statements } & $\begin{array}{c}\text { Definitely } \\
\text { untrue }\end{array}$ & Untrue & True & $\begin{array}{c}\text { Very } \\
\text { True }\end{array}$ \\
\hline $\begin{array}{l}\text { Generally, the Poso people are } \\
\text { religious }\end{array}$ & 2.9 & 12.9 & 60.4 & 23.9 \\
$\begin{array}{l}\text { Every church and mosque want to the } \\
\text { biggest and most impressive }\end{array}$ & 4.6 & 19 & 49.6 & 26.8 \\
$\begin{array}{l}\text { Most people forget the meaning of } \\
\text { brotherhood when they get out } \\
\text { church/mosque }\end{array}$ & 21.7 & 38.3 & 29 & 11 \\
$\begin{array}{l}\text { All religious institutions cooperate } \\
\text { well with one another }\end{array}$ & 4.8 & 18.2 & 52.8 & 24.1 \\
$\begin{array}{l}\text { Churches/mosques are constructive } \\
\text { factor for better community life }\end{array}$ & 1.6 & 3.5 & 44.5 & 50.4 \\
\hline \hline
\end{tabular}

One form of expression on religious identity is the condition of places of worship which are the values tested in the second statement. This study shows that 74 percent of respondents admit that all houses of worship want to look big and impressive as a representative of their religious pride. Even though every religion in Poso wants to look better with the magnificent of their places of worship, however, they try to maintain their brotherhood. This can be seen in the third statement data, where the majority of respondents did not state the truth of the neglect of brotherhood outside the house of worship. This data indicates that the Poso community always maintains interfaith relations to minimize conflict reappearance. The fourth statement confirms the commitment of the Poso people to always maintain relations between adherents of religion. Table 5 shows that 76.9 respondents (include "true" and "very true" statements) stated that religious institutions in Poso worked together. Religious conflicts that have experienced a lesson for Poso residents to maintain cooperation between religious institutions. In the final statement, this study measures respondents' perceptions of the role of religious institutions in community life. Table 5 shows that 94 respondents (include "true" and "very true" statements) supported the statement. This data indicates that young people who were respondents in this study have high hopes for religious institutions to rebuild their trust and social solidarity after a decade of conflict. 


\section{Conclusion}

The Poso people have experienced the collapse of social solidarity among them due to violent religious conflicts. Following Fessler's study, this study aims to measure the degree of social solidarity of the Poso community after more than a decade of conflict has ended, and the Poso community has rebuilt its community and social relations. This study indicates that the Poso community has strong social solidarity. The majority of respondents feel as part of the community and are always open to open relationships with anyone regardless of ethnic or religious background. The study also identified Poso young people have positive interpersonal relationships although they have experienced violent conflict.

This research then analyzes three important social institutions by looking at their contribution to social solidarity, namely family, school, and religious institutions. The data shows that the Poso community made the family a basic social institution in building social norms of the younger generation from an early age. Furthermore, this study also identifies the role of schools in society to build social solidarity through its function as an educational institution. The last social institution is a religious institution which also contributes in shaping social norms and contributing to social solidarity. In short, this study indicates the strong social solidarity of the Poso people after a decade after the conflict.

\section{References}

[1] J. Bertrand.: Nationalism and Ethnic Conflict in Ethiopia (Cambridge: Cambridge University Press) (2004)

[2] S. Shewfelt.: Rebuilding Community after Conflict: Internally Displaced People in Indonesia (2007)

[3] A. A. Yani.: The Local Government and Violent Conflicts Mitigation in the Post Conflict Areas in Indonesia ; a Case Study in the Regency of North Luwu Thesis at Utrecht School of Governance Utrecht University. (2009)

[4] A. Rusyiana, M. R. K. Muluk, and D. Sujarwoto.: Radical Decentralization Reform and Communal Conflict in Indonesia, 2003-2014,in Proceeding International Conference on Administrative Science,Vol.43.pp. 33-38 (2007)

[5] World Ban.: New Patterns of Violence in Indonesia : Preliminary Evidence from Six “ High Conflict Provinces (2010)

[6] M. Kieran.: Reconstructing Trust in Sierra Leone.Round Table, Vol. 98. pp. 461-471 (2009)

[7] E. Durkheim.: The Division of Labor in Society (Glencoe: The Free Press) (1947)

[8] A. Evans.: An Examination of The Concept Social Solidarity, Mid. Am. Rev. Sociol., Vol. 2.pp. 29-46, 1977.

[9] L. K. Alfirdaus, E. Hiariej, and F. Adeney-Risakotta.: Theories of Social Solidarity in the Situation of (Natural) Disasters. Politika Vol. 6.pp. 44-70 (2015)

[10] B. Petrini.: Violent Conflict Dataset 1991 - 2008 1.World Bank (2010)

[11] G. K. Brown and R. Diprose.: Bare-chested Politics in Central Sulawesi, Indonesia: The Dynamics of Local Elections in a'post'-conflict Region (2007)

[12] D. G. Mcrae.: The Escalation and Decline of Violent Conflict in Poso, Central Sulawesi, 19982007. The Australian National University (2008)

[13] World Bank.: Reintegration and Localized Conflict : Promoting Police-Combatant Communication (2009)

[14] BPS Poso.: Kabupaten Poso Dalam Angka 2017 (Poso: Badan Pusat Statistik Poso) (2017)

[15] D. R. Fessler.: The Development of Scale for Community Solidarity," Rural Sociol., Vol. 17.pp. 144-152 (1952)

[16] L. V. Aragon, "Communal Violence in Poso, Central Sulawesi: Where People Eat Fish and Fish Eat People," Indonesia, vol. 72, no. 72, p. 45, 2001.

[17] A. Varshney, R. Panggabean, and M. Z. Tadjoeddin.: Patterns of Collective Violence in Indonesia 1990-2003 (2004) 